\title{
Hanguana fraseriana (Hanguanaceae), a new species from Peninsular Malaysia
}

\author{
J. Leong-Škorničková1 \& R. Kiew ${ }^{2}$ \\ ${ }^{1}$ Herbarium, Singapore Botanic Gardens, National Parks Board, \\ 1 Cluny Road, 259569 Singapore \\ jana_skornickova@nparks.gov.sg \\ ${ }^{2}$ Forest Research Institute Malaysia \\ Kepong 52109, Selangor, Malaysia \\ ruth@frim.gov.my
}

ABSTRACT. Hanguana fraseriana, a new species from Peninsular Malaysia, is described and illustrated here.

Keywords. Fraser's Hill, Hanguana exultans, H. stenopoda, H. triangulata, Pahang

\section{Introduction}

Field-based research on Hanguana Blume in recent years has led to the realisation that a genus that was thought to be monospecific is actually very diverse, with an estimate of at least 50 species in SE Asia (Leong-Škorničková \& Boyce, 2015). Based on the study of herbarium material in several herbaria, we estimate that more than 20 species will be recognised in Peninsular Malaysia. Indeed, several new species have been described recently from Peninsular Malaysia (Siti Nurfazilah et al., 2010, 2011) and Singapore (Niissalo et al., 2014; Leong-Škorničková \& Boyce, 2015). As previously mentioned (Leong-Škorničková \& Boyce, 2015), the best characters for reliable species delimitation and descriptions of new species are from living material of mature fruiting female specimens. Species recognition is possible, but more difficult, from herbarium material if there are mature fruit but becomes much more difficult or impossible if the herbarium material only has flowers (male or female) and no mature fruit.

Here we describe a new species from Fraser's Hill, Peninsular Malaysia. This species was previously listed in the Seed Plant Flora of Fraser's Hill (Kiew, 1998) as Hanguana malayana, following the then-accepted monospecific treatment of the genus by Backer (1951). Examination of 857 herbarium sheets of Hanguana in E, K, KEP, L, P and SING (Thiers, continuously updated) revealed only a single previous record of this species from Fraser's Hill, collected by E.J.H. Corner in 1937, although without exact locality.

An introduction to the genus was given in a recent work by Leong-Škorničková $\&$ Boyce (2015) and is, therefore, not repeated here. The description follows the format outlined in Leong-Škorničková \& Boyce (2015). An introduction to the vegetation of Fraser's Hill has been given by Kiew (1998). 


\section{Hanguana fraseriana Škorničk. \& Kiew, sp. nov.}

Similar to Hanguana triangulata Škorničk. \& Boyce, but differs in less prominently corrugated leaves, overall longer infructescence branches (median branches of lower partial infructescences $16-21 \mathrm{~cm}$ versus $6-8 \mathrm{~cm}$ in $H$. triangulata), by stigma shape (stigma lobes ovate, connate at base with round apices forming a trefoil shape versus stigma lobes trullate, connate at base with sharply acute apices forming a sharply equilateral triangular structure in $H$. triangulata) and the seed appendage (broadly triangular appendage versus a blunt appendage composed of two sub-lobes in $H$. triangulata). - TYPE: Peninsular Malaysia, Pahang, Fraser's Hill, along Bishop Trail, c. $1200 \mathrm{~m}$ asl, 11 September 2014, R. Kiew \& J. Leong-Škorničková FRI89123 (holotype KEP (mounted on 5 sheets and inclusive of fruit in spirit); isotypes K, SING (both also mounted on 5 sheets and inclusive of fruit in spirit)). (Fig. 1, 2)

Herbaceous, dioecious mesophyte to c. $1.4 \mathrm{~m}$ tall; stem terete, to $3 \mathrm{~cm}$ in diam., basally semi-ascending, with age becoming leafless and 'woody' (up to $40 \mathrm{~cm}$ in length), terminally ascending with crown of up to 25 leaves; stolons absent. Leaves to 145 $\mathrm{cm}$ long, spreading and arching; bases imbricate, margins hyaline (young leaves), turning erose-marcescent with age; pseudopetiole 40-55 $\mathrm{cm}$ long, 8-10 $\mathrm{mm}$ wide, accounting for 1/3-1/2 of entire leaf length, canaliculate with sharp margins, sparsely softly flocculose; leaf blade 60-90 × 12-15.4 cm, narrowly elliptic, base attenuate, tip long narrowly attenuate, leathery, adaxially dark green, shiny, glabrous, abaxially matte mid-green, covered with silky flocculose hair (visible in young leaves, falling off with age); midrib weakly impressed, almost of same colour as rest of lamina, glabrous adaxially, round-raised, mid green, sparsely flocculose abaxially. Female and male inflorescences not observed, although, based on observations of infructescence architecture, almost certainly erect at anthesis. Female flowers scattered, always solitary, sessile, each with an associated minute bracteole; perianth composed of 6 tepals in two whorls tightly clasping ovary/fruit in fresh material, all tepals with prominent bulbous thickening at base (more prominent in outer whorl), light green, margin $0.4-0.5 \mathrm{~mm}$ wide, hyaline translucent white; outer tepals broadly ovate, c. $2 \mathrm{~mm}$ long, 3.5-4 mm broad, free to base, sparsely arachnoid; inner tepals broadly ovate, c. $3.5 \mathrm{~mm}$ long, c. $4.5 \mathrm{~mm}$ broad, free to base, almost glabrous (occasionally sparsely arachnoid); staminodes 6 , in two whorls, cream-white, triangular to narrowly triangular, outer staminodes minute, triangular, c. $0.6 \mathrm{~mm}$ long, $0.5 \mathrm{~mm}$ broad at base, inner staminodes larger, c. $1.5 \mathrm{~mm}$ long, $0.7 \mathrm{~mm}$ at base, each with basal staminodial scale, c. $0.6 \mathrm{~mm}$ long, and c. $1 \mathrm{~mm}$ broad, irregularly rectangular with blunt corners, brown with translucent margin. Stigma 3-lobed, each lobe c. 1-1.2 mm long (fruiting material), lobes ovate with round apices, basally connate (rarely imperfectly so) forming trefoil-like structure (c. $2 \mathrm{~mm}$ in diam. in fruiting material), raised, matte dark brown in late fruiting stage. Infructescence erect, comprising of up to 8 partial, whorled, alternate-secund, thyrsoid infructescences plus a terminal spike; partial infructescences spreading, almost perpendicular to rachis (very weakly ascending); peduncle and rachis together up to $110 \mathrm{~cm}$ tall, mid-green when fresh, conspicuously grey-flocculose, visible portion of peduncle up to c. $40 \mathrm{~cm}$ long; sterile bracts two per 


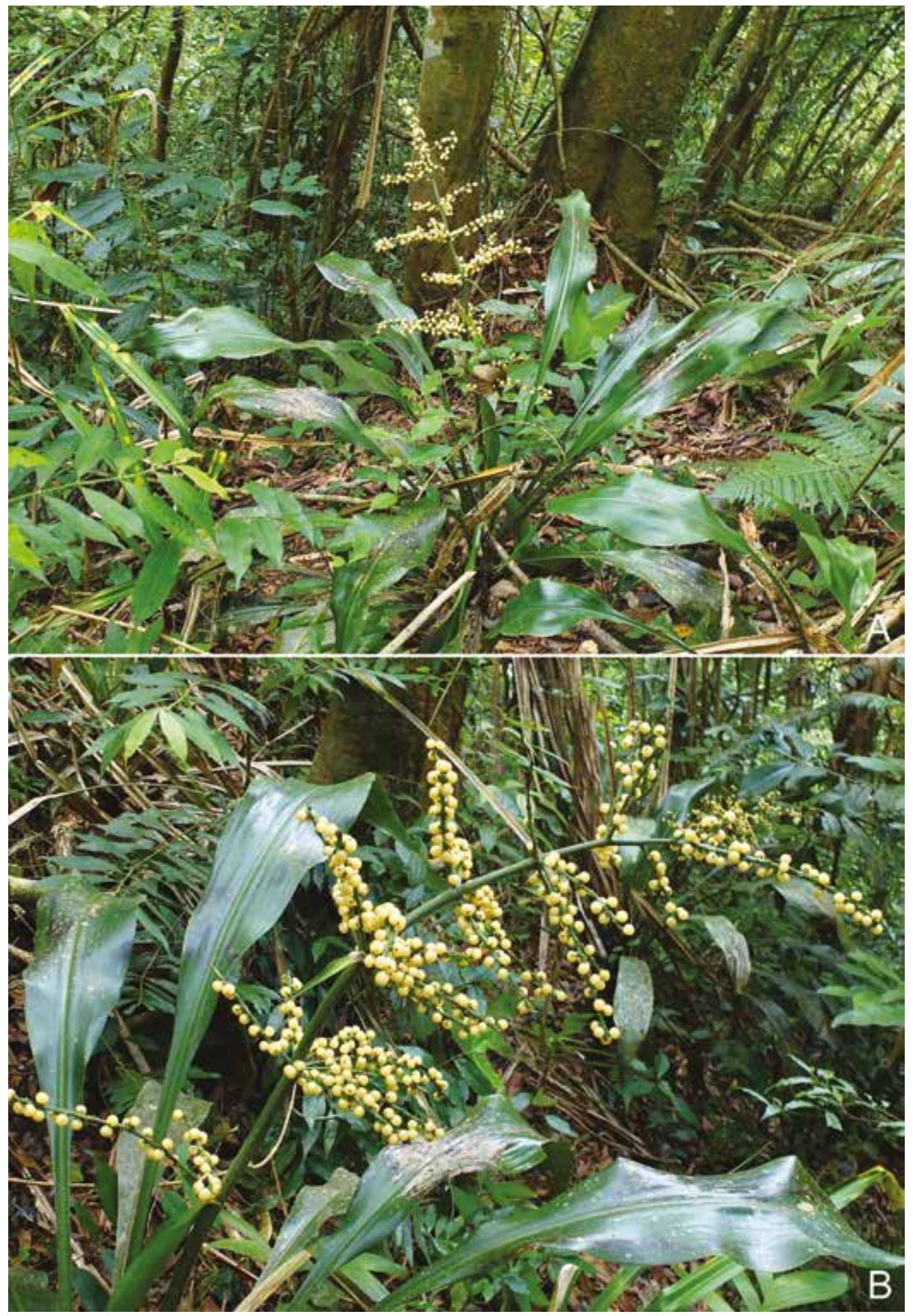

Fig. 1. Hanguana fraseriana Škorničk. \& Kiew. A. Habit. B. Close-up of an infructescence. From type FRI89123. (Photos: J. Leong-Škorničková) 
peduncle, foliaceous, ovate with a basal claw, persistent, lower bract 70 (incl. claw) $\times$ 13.2 (at widest) $\mathrm{cm}$, upper bract 43 (incl. claw) $\times 10.3 \mathrm{~cm}$; bract subtending the lowest partial infructescence similar to sterile bracts $27 \times 6 \mathrm{~cm}$, bracts at upper infructescences diminishing in size distally along the infructescence into small narrowly triangular bracts, and fully reduced in uppermost partial infructescences; partial infructescences each comprising of up to 10 branches at basal levels (less towards the apex of the inflorescence); branches simple (with no further branching), arising simultaneously from the axil of the subtending bract, lateral branches progressively shorter in length (outermost lateral branches 2/3-1/2 of the median branch); median branch 16-21 $\mathrm{cm}$ long (in lower infructescences), c. $3 \mathrm{~mm}$ in diam. Fruit cream to pale yellow externally (almost ripe), pulp 1-2 mm thick, hard, cream-white, globose or almost so (depending on number of seeds ripening), 7-10 $\mathrm{mm}$ diam., ripening from bright green to cream to pale yellow; seeds one to three per fruit (almost ripe), c. $6 \times 5 \mathrm{~mm}$, pale brown (expected to darken when fully ripe), broadly boat-shaped to bowl-shaped, deeply excavated, with a broadly triangular appendage with more or less blunt apex positioned on the distal part of the rim, cavity filled with placental tissue.

Eponymy. Named for James Louis Fraser, who in the 1890s lived and died at the place, Fraser's Hill, that later took his name.

Distribution and Ecology. So far known only from the Fraser's Hill, Pahang, Peninsular Malaysia. This species grows on steep slopes in the undergrowth of broadleaved lower montane forest, at c. $1200 \mathrm{~m}$ altitude.

Preliminary IUCN conservation assessment. This species is so far known only from the Fraser's Hill in certain parts of Bishop and Maxwell's trails, where the total number of the adult individuals does not exceed 30. It is likely that this species is also distributed in the surrounding hills, but until better evidence surfaces, we propose, in lines with IUCN recommendations (IUCN, 2012), to treat Hanguana fraseriana as Data Deficient.

Additional specimens examined. PENINSULAR MALAYSIA: Pahang: Fraser's Hill, 12 Aug 1937, Corner, E.J.H. s.n. (SING).

Notes. So far seven species of Hanguana have been described from Peninsular Malaysia. Of these only two lowland species, Hanguana exultans Siti Nurfazilah et al. and $H$. stenopoda Siti Nurfazilah et al., have fruits creamy white at maturity and therefore could potentially be mistaken for this species. Hanguana exultans can be distinguished by the partial infructescences with fewer and much shorter branches (up to 7 branches per partial infructescence, with median branches c. $9 \mathrm{~cm}$ long), which are sharply ascending in the fruiting stage, and a stigma comprised of three free lobes. Hanguana stenopoda, although with similar stigma structure, has a dark brown-red peduncle and rachis in the fresh state, fewer and shorter branches (up to 4 branches per partial infructescence, with median branches c. 5-7 cm long) and female flowers are mainly arranged in groups of two or three. 

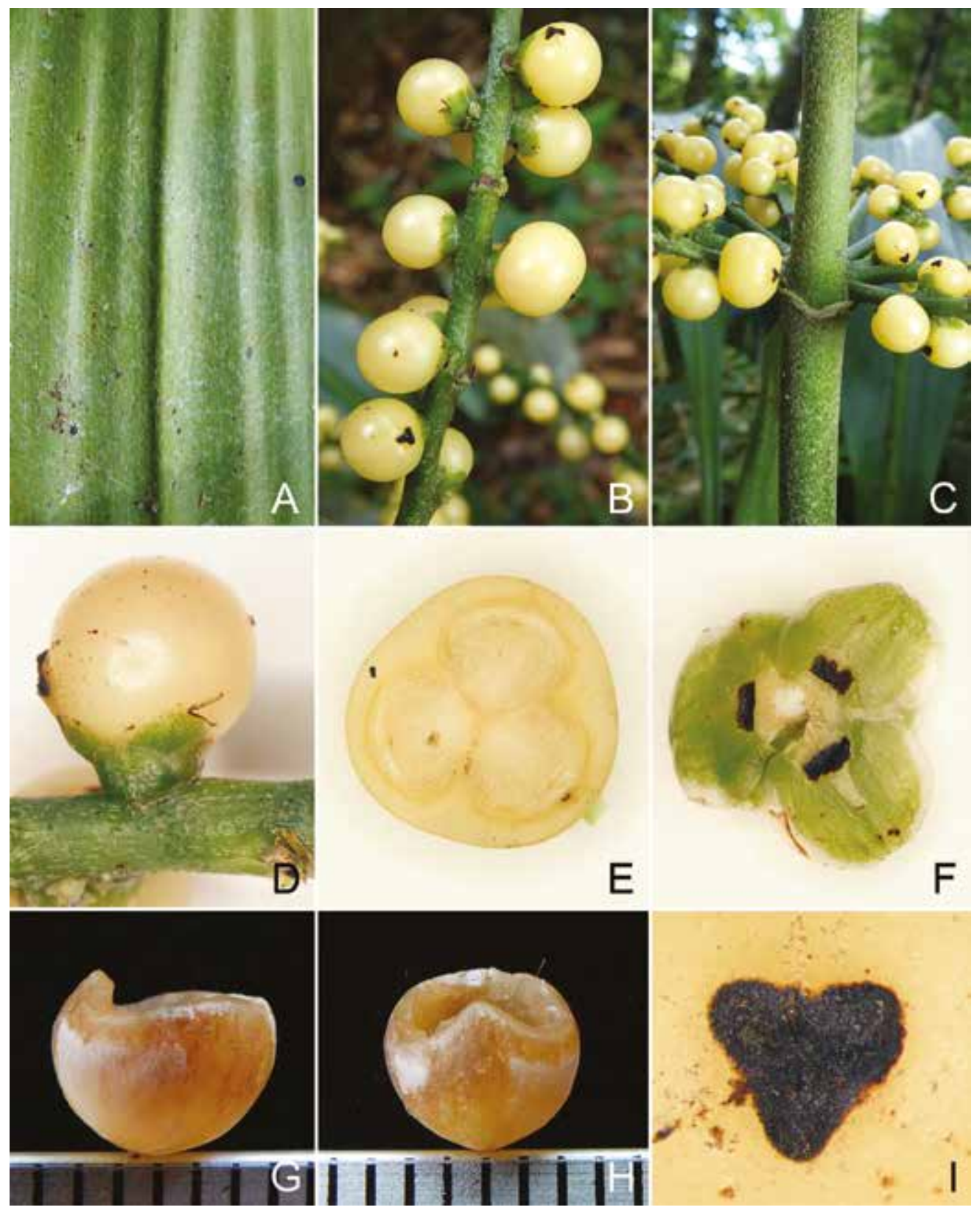

Fig. 2. Hanguana fraseriana Škorničk. \& Kiew. A. Close up of leaf indumentum (abaxial side). B. Detail of fruits. C. Detail of rachis with a dense flocculose indumentum. D. Side view of a fruit, showing tepals and obliquely positioned stigma. E. Cross-section of a fruit with three seeds. F. Detail of inner tepals, staminodes and staminodial scales. G. Young seed (lateral view; scale in mm). H. Young seed (front view; scale in mm). From type FRI89123. (Photos: J. Leong-Škorničková) 
ACKNOWLEDGEMENTS. We thank the curators of KEP and SING for allowing us to examine the specimens in their care. The herbaria E, K, L and $\mathrm{P}$ are thanked for their extensive on-line resources, which allowed us to review Hanguana sheets online. The research of JL-ŠS is supported by the National Parks Board Singapore, the research of RK is part of the Flora of Peninsular Malaysia project (no. 01-04-01-0000 Khas) funded by the Ministry of Science, Technology and Innovation. We thank the Fraser's Hill Development Board for permission to carry out research at Fraser's Hill.

\section{References}

Backer, C.A. (1951). Hanguana. In: Van Steenis, C.G.G.J. (ed) Flora Malesiana, ser. 1, 4(3): $248-250$.

IUCN (2012). IUCN Red List Categories and Criteria: Version 3.1. Second edition. Gland, Switzerland and Cambridge, UK: IUCN.

Kiew, R. (1998). The Seed Plant Flora of Fraser's Hill, Peninsular Malaysia, With Special Reference to Its Conservation Status. Kuala Lumpur: Forest Research Institute Malaysia

Leong-Škorničková, J. \& Boyce, P.C. (2015). Hanguana in Singapore demystified: an overview with descriptions of three new species and a new record. Gard. Bull. Singapore 67(1): $1-28$.

Niissalo, M., Wijedasa, L., Boyce, P.C. \& Leong-Škorničková, J. (2014). Hanguana neglecta (Hanguanaceae): a new plant species from a heavily collected and visited reserve in Singapore. Phytotaxa 188(1): 14-20.

Siti Nurfazilah, A.R., Mohd Fahmi, A.B., Ahmad Sofiman, O. \& Boyce, P.C. (2010). Studies on Hanguana (Commelinales-Hanguanaceae) for Sunda II: Five new forest species, a new species record from Peninsular Malaysia, and a redefinition of the taxonomic limits of Hanguana malayana. Willdenowia 40: 205-219.

Siti Nurfazilah, A.R., Ahmad Sofiman, O. \& Boyce, P.C. (2011). Studies on Hanguana (Commelinales-Hanguanaceae) for Sunda I: Hanguana bakoensis, a new forest species from Sarawak, Malaysian Borneo, and notes on critical morphologies for elucidating Hanguana taxonomy. Acta Phytotax. Geobot. 61(3): 139-143.

Thiers, B. (continuously updated). Index Herbariorum: A global directory of public herbaria and associated staff. New York Botanical Garden's Virtual Herbarium. http://sweetgum. nybg.org/science/ih/ (accessed on 12 Jun. 2016). 